\title{
PEMBELAJARAN TEMATIK TERPADU BERBASIS PENDEKATAN SAINTIFIK DI TAMAN KANAK-KANAK
}

\author{
DADAN SURYANA \\ Universitas Negeri Padang \\ Jl. Prof Hamka Air Tawar Padang Sumatera Barat \\ Email: dadan.suryana@yahoo.com
}

\begin{abstract}
This study aims to achieve the ability to observe, ask, try, reason, and communicate through the development of the themes that have been implemented. The learning process experienced by children in an effort to discovery learning. The process of developing the ability to think this is a process of discovery learning as meaningful learning. This meaningful learning required by younger children as a learning process that will be the foundation of knowledge in dealing with the stage of development thinking that will ultimately provide a solid foundation in the face of continued education stage. The process of learning through scientific approach is very appropriate if delivered through an integrated thematic approach. Thematic learning integrated is learning that can instill the basic concepts of knowledge, to increase knowledge of facts, and can provide an interesting learning because the theme is deliver that is very close to the child, simple, attractive, and incidental (according to the event is happening), This study uses a method research and development of Borg \& Gall with six (6) steps of development. Through ten steps of this development will provide easy steps to serve as the research methods of thematic development of teaching materials based integrated scientific approach in kindergarten in West Sumatra.
\end{abstract}

Keywords: Thematic, scientific, early childhood

\begin{abstract}
Abstrak: Penelitian ini bertujuan untuk mencapai kemampuan mengamati, menanya, mencoba, menalar, dan mengomunikasikan melalui pengembangan tema-tema yang selama ini dilaksanakan. Proses pembelajaran yang dialami oleh anak sebagai upaya discovery learning. Proses pengembangan kemampuan berpikir ini merupakan proses penemuan pembelajaran sebagai pembelajaran yang bermakna. Pembelajaran bermakna ini diperlukan oleh anak usia dini sebagai proses pembelajaran yang akan menjadi landasan pengetahuan dalam menghadapi tahap perkembangan berpikir yang pada akhirnya akan memberikan landasan yang kokoh dalam menghadapi tahap pendidikan lanjutan. Proses pembelajaran melalui pendekatan saintifik ini sangat tepat jika disampaikan melalui pendekatan tematik terpadu. Pembelajaran tematik terpadu adalah pembelajaran yang dapat menanamkan konsep dasar pengetahuan, dapat menambah pengetahuan berupa fakta, dan dapat memberikan pembelajaran yang menarik karena tema yang dismapaikan adalah tema yang sangat dekat dengan anak, sederhana, menarik, dan insidental (sesuai dengan peristiwa yang sedang terjadi). Penelitian ini menggunakan penerlitian Metode research and development dari Borg \& Gall dengan 6 (enam) langkah pengembangan. Melalui sepuluh langkah pengembangan ini akan memberikan langkah yang mudah untuk dijadikan sebagai metode penelitian pengembangan bahan ajar tematik terpadu berbasis pendekatan saintifik di Taman Kanak-kanak di Sumatera Barat.
\end{abstract}

Kata Kunci: Tematik terpadu, pendekatan saintifik, taman kanak-kanak 
Pembelajaran merupakan proses ilmiah. Karena itu Kurikulum 2013 mengamanatkan esensi pendekatan ilmiah dalam pembelajaran. Pendekatan ilmiah diyakini sebagai titian emas perkembangan dan pengembangan sikap, keterampilan, dan pengetahuan anak didik. Dalam pendekatan atau proses kerja yang memenuhi kriteria ilmiah, para ilmuwan lebih mengedepankan pelararan induktif (inductive reasoning) ketimbang penalaran deduktif (deductive reasoning). Penalaran deduktif melihat fenomena umum untuk kemudian menarik simpulan yang spesifik. Sebaliknya, penalaran induktif memandang fenomena atau situasi spesifik untuk kemudian menarik simpulan secara keseluruhan. Sejatinya, penalaran induktif menempatkan bukti-bukti spesifik ke dalam relasi idea yang lebih luas. Metode ilmiah umumnya menempatkan fenomena unik dengan kajian spesifik dan detail untuk kemudian merumuskan simpulan umum.

Metode ilmiah merujuk pada teknik-teknik investigasi atas fenomena atau gejala, memperoleh pengetahuan baru, atau mengoreksi dan memadukan pengetahuan sebelumnya. Untuk dapat disebut ilmiah, metode pencarian (method of inquiry) harus berbasis pada buktibukti dari objek yang dapat diobservasi, empiris, dan terukur dengan prinsip-prinsip penalaran yang spesifik. Karena itu, metode ilmiah umumnya memuat serial aktivitas pengoleksian data melalui observasi dan ekperimen, kemudian memformulasi dan menguji hipotesis.

Pembelajaran anak usia dini harus dapat memberikan kesempatan kepada anak untuk mendapatkan proses pembelajaran yang ilmiah. Hal ini akan berdampak kepada kemampuan berpikir dan wawasan anak saat mereka melanjutkan pendidikan ke jenjang yang lebih tinggi. Proses ilmiah yang dapat dilakukan adalah dengan pendekatan saintifik. Proses anak dalam mendapatkan pengetahuan melalui proses mengamati, menanya, mencoba, menalar dan mengomunikasikan. 
Kenyataan di lapangan menunjukkan bahwa guru Taman Kanak-kanak belum mempunya rujukan yang dapat di jadikan pegangan dalam proses belajar mengajar, belum ada bahan ajar tematik terpadu berbasis pendekatan saintifik. Hal ini mengakibatkan guru mengajar tidak sesuai dengan proses pembelajaran melalui pendekatan saintifik. Penelitian Hibah Bersaing ini dapat mengatasi masalah bahan ajar bagi guru yang akan mengajar di Taman Kanak-kanak dan bahan ajar yang dihasilkan dari penelitian ini dapat dijadikan pegangan dan rujukan.

\section{Pembelajaran Ilmiah}

Pembelajaran

berbasis

pendekatan ilmiah itu lebih efektif hasilnya dibandingkan dengan pembelajaran tradisional. Hasil penelitian membuktikan bahwa pada pembelajaran tradisional, retensi informasi dari guru sebesar 10 persen setelah lima belas menit dan perolehan pemahaman kontekstual sebesar 25 persen. Pada pembelajaran berbasis pendekatan ilmiah, retensi informasi dari guru sebesar lebih dari 90 persen setelah dua hari dan perolehan pemahaman kontekstual sebesar 50-70 persen.

Proses pembelajaran harus dipandu dengan kaida-kaidah pendekatan ilmiah. Pendekatan ini bercirikan penonjolan dimensi pengamatan, penalaran, penemuan, pengabsahan, dan penjelasan tentang suatu kebenaran. Dengan demikian, proses pembelajaran harus dilaksanakan dengan dipandu nilainilai, prinsip-prinsip, atau kriteria ilmiah. Proses pembelajaran disebut ilmiah jika memenuhi kriteria seperti berikut ini. Substansi atau materi pembelajaran berbasis pada fakta atau fenomena yang dapat dijelaskan dengan logika atau penalaran tertentu; bukan sebatas kira-kira, khayalan, legenda, atau dongeng semata. Penjelasan guru, respon anak didik, dan interaksi edukatif guruanak didik terbebas dari prasangka yang serta-merta, pemikiran subjektif, atau penalaran yang menyimpang dari alur berpikir logis. Mendorong dan menginspirasi anak didik berpikir secara kritis, analistis, dan tepat dalam mengidentifikasi, memahami, memecahkan masalah, dan mengaplikasikan substansi atau 
materi pembelajaran. Mendorong dan menginspirasi anak didik mampu berpikir hipotetik dalam melihat perbedaan, kesamaan, dan tautan satu sama lain dari substansi atau materi pembelajaran. Mendorong dan menginspirasi anak didik mampu memahami, menerapkan, dan mengembangkan pola berpikir yang rasional dan objektif dalam merespon substansi atau materi pembelajaran. Berbasis pada konsep, teori, dan fakta empiris yang dapat dipertanggungjawabkan. Tujuan pembelajaran dirumuskan secara sederhana dan jelas, namun menarik sistem penyajiannya.

\section{Pendekatan Saintifik dalam Pembelajaran}

Implementasi kurikulum

2013 dalam pembelajaran dengan pendekatan saintifik adalah proses pembelajaran yang dirancang sedemikian rupa agar anak didik secara aktif mengonstruk konsep, hukum atau prinsip melalui tahaptahapan mengamati (untuk mengidentifikasi atau menemukan masalah), merumuskan maalah, mengajukan atau merumuskan hipotesis, mengumpulkan data dengan berbagai teknik, menganalisis data, menarik kesimpulan dan mengomunikasikan konsep, hukum atau prinsip yang “ditemukan". Pendekatan saintifik dimaksudkan untuk memberikan pemahaman kepada anak didik dalam mengenal, memahami berbagai materi menggunakan pendekatan ilmiah, bahwa informasi bisa berasal dari mana saja, kapan saja, tidak bergantung pada informasi searah dari guru. Oleh karena itu, kondisi pembelajaran yang diharapkan tercipta diarahkan untuk mendorong anak didik dalam mencari tahu dari berbagai sumber melalui observasi, dan bukan hanya diberitahu (Hosnan 2013).

Penerapan pendekatan saintifik dalam pembelajaran dalam pembelajaran melibatkan katerampilan proses, seperti mengamati, mengklasifikasi, mengukur, meramalkan, menjelaskan, dan menyimpulkan. Dalam melaksanakan proses-proses tersebut, bantuan guru diperlukan. Metode saintifik sangat relevan dengan tiga teori belajar, yaitu teori 
Bruner, teori Piaget, dan teori Vygotsky. Teori belajar Bruner disebut juga teori belajar penemuan. Ada empat hal pokok berkaitan dengan teori belajar Bruner. Pertama, individu hanya belajar dan mengembangkan pikirannya apabila ia menggunakan pikirannya. Kedua, dengan melakukan proses-proses kognitif dalam proses penemuan, anak akan memperoleh sensasi dan kepuasan intelektual yang merupakan suatu penghargaan intrinsik. Ketiga, satu-satunya cara agar seseorang dapat mempelajari teknik-teknik dalam melakukan penemuan adalah ia memiliki kesempatan untuk melakukan penemuan. Keempat, dengan melakukan penemuan maka akan memperkuat retensi ingatan. Empat hal di atas adalah bersesuaian dengan proses kognitif yang diperlukan dalam pembelajaran menggunakan metode saintifik.

Teori Piaget, menyatakan bahwa belajar berkaitan dengan pembentukan dan perkembangan skema (jamak skematan). Skema adalah suatu struktur mental atau struktur kognitif yang dengannya seseorang secara intelektual beradaptasi dan mengkoordinasi lingkungan sekitarnya. Skema tidak pernah berhenti berubah, skemata seorang anak akan berkembang menjadi skemata orang dewasa. Proses yang menyebabkan terjadinya perubahan skemata tersebut dengan adaptasi. Proses terbentuknya adaptasi ini dapat dilakukan dengan dua cara, yaitu asimilasi dan akomodasi. Asimilasi merupakan proses kognitif yang dengannya seseorang mengitegrasikan stimulus yang dapat berupa persepsi, konsep, hukum, prinsip ataupun pengalaman baru ke dalam skema yang sudah ada di dalam pikirannya. Akomodasi dapat berupa pembentukan skema baru yang dapat cocok dengan ciriciri rangsangan yang ada atau memodifikasi skema yang telah ada sehingga cocok dengan ciri-ciri stimulus yang ada. Dalam pembelajaran diperlukan adanya penyeimbangan atau ekuilibrasi antara asimilasi dan akomodasi (Jackman 2009).

Vygotsky dalam teorinya menyatakan bahwa pembelajaran terjadi apabila anak didik bekerja 
atau belajar menangani tugas-tugas yang belum dipelajari namun tugastugas itu masih berada dalam jangkauan kemampuan atau tugas itu berada dalam zone of proximal development daerah terletak antara tingkat perkembangan anak saat ini yang didefinisikan sebagai kemampuan pemecahan maalah di bawah bimbingan orang dewasa atau teman sebaya yang lebih mampu.

b. Karakteristik Pendekatan Saintifik Pembelajaran dengan pendekatan saintifik memiliki karakteristik pembelajaran berpusat pada anak; melibatkan keterampian proses sains dalam mengonstruksi konsep, hukum atau prinsip; melibatkan proses-proses kognitif yang potensial dalam merangsang perkembangan intelek, khususnya keterampilan berpikir tingkat tinggi; dapat mengembangkan karakter anak (Hosnan 2013).

1) Tujuan pembelajaran dengan pendekatan saintifik

Tujuan pembelajaran dengan pendekatan saintifik didasarkan pada keunggulan pendekatan tersebut. Beberapa tujuan pembelajaran dengan pendekatan saintifik adalah untuk meningkatan kemampuan intelektual anak, khususnya kemampuan berpikir tingkat tinggi anak; untuk membentuk kemampuan anak dalam menyelesaikan suatu masalah secara sistematik; terciptanya kondisi pembelajaran di mana anak merasa bahwa belajar merupakan suatu kebutuhan; diperolehnya hasil capaian perkembangan yang signifikan; untuk melatih anak dalam mengomunikasikan ide-ide khususnya dalam menghasilkan suatu karya atau pekerjaan; untuk mengembangkan karakter anak.

2) Prinsip-prinsip pembelajaran dengan pendekatan saintifik

Beberapa prinsip pendekatan saintifik dalam kegiatan pembelajaran adalah pembelajaran berpusat pada anak; pembelajaran membentuk students self concept; pembelajaran terhindar dari verbalisme; pembelajaran memberikan kesempatan pada anak untuk mengasimilasi dan mengakomodasi konsep, hukum, dan prinsip pembelajaran; pembelajaran mendorong terjadinya peningkatan kemampuan berpikir anak; 
pembelajaran meningkatkan motivasi belajar anak dan motivasi mengajar guru.

\section{METODE PENELITIAN}

Metodologi yang dipilih untuk penelitian ini adalah penelitian Research and Development, metode Research and Development merupakan pilihan karena memiliki proses yang lebih kompleks dalam tahap-tahapan yang dapat mengakomodasi beragam kepentingan penelitian ini. (Borg 1989:784) Pendidikan yang dikembangkan merupakan produk pengajaran terkait dengan teknologi pengajaran yang membutuhkan justifikasi dalam proses pembelajaran. Konsekuensinya peneliti membutuhkan waktu yang panjang untuk membaca banyak buku dan teori, melakukan kunjungan dan melakukan focus group discussion ke berbagai pihak dan masuk ke sekolah untuk memberikan pengetahuan kepada guru agar dapat merasakan dan menemukan berbagai fakta dan kondisi penyampaian dan tanggapan kegiatan pembelaajran berbasis saintifik anak. Metode Research and Development membutuhkan proses dan menuntut semangat yang kuat, ketekunan, pengamatan yang dalam dan kritis, serta kesabaran panjang dalam memancing keluarnya berbagai gagasan kreatif.

Model pembeajaran melalui pendekatan saintifik untuk anak usia Taman Kanak-kanak ini merupakan salah satu desain teknologi pengajaran yang membutuhkan metodologi yang tepat sebagai wahana (vehicle) untuk sebuah kepentingan penelitian yang holistik dengan serangkaian proses yang mesti dijalani dengan terstruktur, terencana, dan terkontrol. Untuk itu kemudian ditentukan wilayah dan langkah-langkah kerja penelitian ini menjadi sepuluh tahapan, berpedoman pada metode Research and Development yang dikembangkan Borg and Gall dengan penjabaran sebagai berikut (Borg 1989: 775). 
Langkah Utama Borg And Gall

Research \& Information Collecting

Planning

Develop Preliminary form of Product

Field testing \& Product Revision
Final Product Revision

Dissemination \& Implementation

Langkah-langkah penelitian dan pengembangan (Borg 1989: 192). Penjelasaan setiap tahapnya adalah sebagai berikut :

\section{Tahap} pertama, mengumpulkan informasi (research and information collecting). Dalam penelitian ini terkait kajian informasi tentang kegiatan pembelajaran di Taman Kanak-kanak serta informasi tambahan lainnya terkait dengan kegiatan pembelajaran, kemudian kajian pustaka yang menyangkut teoritis tentang hakikat Aspek perkembangan Anak usia dini, metode pembelajaran.

Tahap kedua, melakukan perencanaan (planning), yang dalam
10 Langkah Borg \& Gall

\author{
Penelitian dan Pengumpulan informas \\ Perencanaan \\ Pengembangan Product awal \\ Uji Lapangan awal (Preliminary) \\ Revisi Produk \\ Uji Lapangan Utama (main) \\ Revisi Produk Operasional \\ Uji Lapangan Akhir \\ Revisi Produk Akhir \\ Diseminasi dan Implementasi
}

penelitian ini melakukan serangkaian kajian pustaka dan teori (Studi Literatur), diskusi dengan para guru dan kepala sekolah, para pakar pendidikan. Kemudian mendapatkan temuan, konsensus, proposisi, dan generalisasi untuk dipahami (verstehen) terhadap materi-materi pendidikan di Taman kanak-kanak yang cocok diberikan kepada anakanak tingkat Taman Kanak-kanak, focus group discussion dengan para guru, kepala sekolah, dan Dinas Pendidikan Provinsi dan kota. Hal ini tentu saja mempengaruhi volume materi tulisan dan berbagai pendapat para ahli. 
Tahap

ketiga,

mengembangkan

pembelajaran

(develop preliminary form of

product) dalam penelitian ini

merupakan desain model bahan ajar

tematik terpadu berbasis pendekatan

saintifik terkait dengan persiapan

proses pembelajaran menyangkut

materi, proses dan evaluasi dengan

melakukan sosialisasi berupa diskusi

bersama berbagai kalangan.

Tahap keempat, sebelumnya

sudah dilakukan ujicoba terbatas pada tahun kedua, maka

dikembangkan instrumen ukur sesuai dengan kegiatan yang

dikembangkan, dikalibrasi dan kemudian dilakukan ujicoba terbatas di lapangan (preliminary field testing) untuk menjustifikasi pembelajaran yang dikembangkan yang dalam penelitian ini dipadukan dengan metode action research dengan menggunakan dua putaran siklus saja, yaitu melalui fase permulaan (initiation), fase penemuan (detection), dan fase keputusan (judgment). (Schumck 1996: 50-52)

Tahap kelima, pada tahap ke lima melakukan revisi (main product revision) melakukan focus group interview yang terdiri dari para guru TK dan kepala sekolah di lokasi ujicoba. Setelah pendidikan final maka dilakukan Ujicoba efektifitas pembelajaran.

Tahap keenam, difusi luas yang dalam penelitian ini sosialisasi secara makro dilakukan pada tahun ke tiga.

Sementara Borg dan Gall dalam Semiawan mengembangkan Research and Development ke dalam tiga siklus, yaitu (1) siklus kajian, (2) siklus evaluasi, dan (3) siklus pengembangan melalui enam tahapan sesuai metode Research and Development melalui pemetaan wilayah dan langkah-langkah kegiatan seperti yang terdapat pada bagan berikut ini (Semiawan, 2007: 181-187). 
Bagan 1

Siklus Penelitian Research and Development

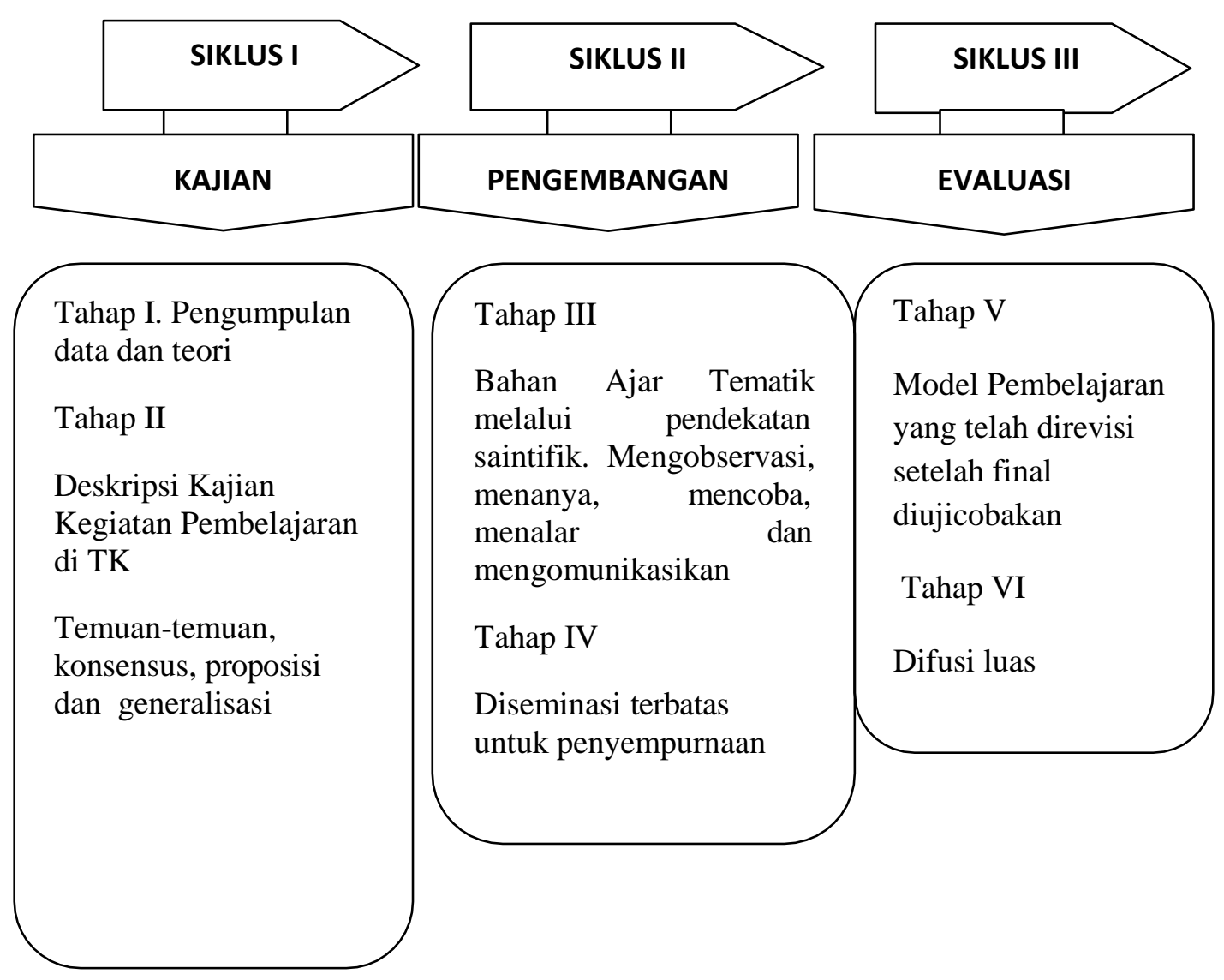

Adapun rinciannya sebagai

berikut:

Siklus I Pertama dari tiga siklus Research and Development ini akan dilakukan serangkaian kajian yang terdiri atas dua tahapan.

Tahap pertama mengumpulkan informasi (research and information collection), terkait dengan kajian pustaka yang menyangkut teoritis tentang pendekatan saintifik yaitu mengamati, menanya, mencoba, menalar, dan mengomunikasikan. Dari teori dan kajian isu-isu mutakhir lainnya ini terbentuklah desain kajian anak usia dini seperti bagan berikut: 


\section{Bagan 2}

Desain Kajian Model Pembelajaran Pendekatan Saintifik

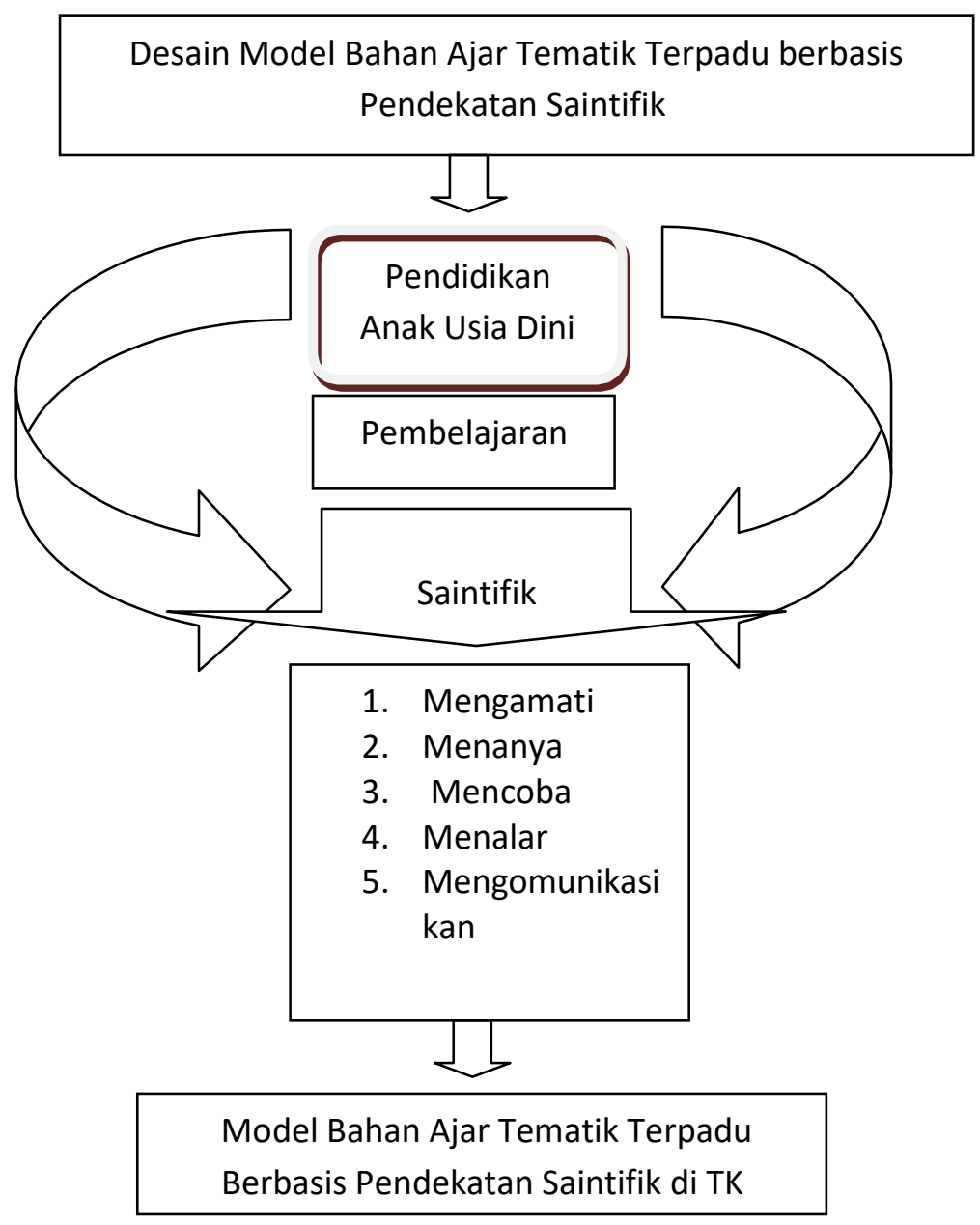

Tahap kedua, melakukan focus group discussion dengan para perencanaan (planning), yang dalam guru dan kepala sekolah.

penelitian ini melakukan serangkaian kajian tentang pendidikan anak usia dini menyangkut aspek perkembangan, pembelajaran dan pendekatan saintifik yang kemudian mendapatkan temuan, konsensus, proposisi, dan generalisasi untuk dipahami (verstehen) melalui
Siklus II Melakukan Evaluasi dengan melalui dua tahapan sebagai berikut:

Tahap ketiga, merupakan pengembangan konsep aplikatif berupa pemetaan materi pendekatan saintifik yang patut untuk Taman Kanak-kanak yang dilakukan di 
sekolah. Selanjutnya dikembangkan sebuah model pembelajaran pendekatan saintifik dari kajian setiap tahap.

Tahap keempat, Mengembangkan Instrumen ukur, dikalibrasi dan melakukan ujicoba terbatas di lapangan (preliminary field testing) untuk melihat kesesuaian materi di lapangan dengan perkembangan anak khususya meng observasi pengetahuan para guru dan kepala sekolah terkait dengan pengembangan kognitif anak. Selanjutnya penelitian ini dipadukan dengan metode action research agar dapat menjustifikasi pembelajaran yang dikembangkan untuk melihat sejauh mana signifikansi dengan perubahan terhadap perkembangan anak dengan menggunakan satu siklus putaran saja, melalui serangkaian fase, yaitu fase permulaan (initiation), fase penemuan (detection), dan fase keputusan (Judgment). (Schmuck, 1996: 50-52)Metode ini sangat membantu melakukan penyesuaianpenyesuaian secepatnya pada saat terjadi perubahan pada objek yang diteliti.
Siklus III Merupakan pengembangan yang terdiri atas dua tahap:

Tahap kelima, melakukan perbaikan dan sudah diujicobakan secara terbatas. Dan perbaikan pembelajaran ini akan dihasilkan sebuah model pembelajaran sebagai studi rintisan yang siap untuk dikembangkan dan direplikasi.

Tahap keenam, sebuah pembelajaran siap ditransferabilitaskan.

Analisis data dilakukan dengan kualitatif deskriptif. Data yang dianalisis dalam penelitian ini adalah 1) Data identifikasi sekolah dan guru 2) Data pengetahuan pengembangan kognitif 3) Data uji hasil penelitian Research and Development 4) Data hasil analisis penelitian.

Instrumen penelitian Research and Development ini menggunakan lembar observasi, wawancara dan dokumentasi dilengkapi dengan perangkat evaluasi lainnya berupa instrumen ukur dan daftar pertanyaan yang disusun berdasarkan kebutuhan lapangan. Instrumen pertanyaan terhadap para guru berisi informasi 
mengenai data mendasar, wawasan dan pengetahuan yang diteliti. Selain itu juga disusun instrumen yang mengumpulkan informasi pendukung melalui "most significant change" yang memberikan reaksi perubahan seketika terhadap sekolah yang diteliti (Hopkins 1993). Melalui instrumen ini akan ada masukan dan koreksi sebagai perbaikan terhadap pendidikan yang dilaksanakan dalam penelitian.

\section{HASIL DAN PEMBAHASAN}

Hasil penelitian ini sangat terkait dengan 10 (sepuluh) tahap pengembangan model penelitian pengembangan menurut Borg dan Gall, yaitu:

\section{Tahap}

pertama,

mengumpulkan informasi (research and information collecting). Dalam penelitian ini terkait kajian informasi tentang kegiatan pembelajaran di Taman Kanak-kanak serta informasi tambahan lainnya terkait dengan kegiatan pembelajaran, kemudian kajian pustaka yang menyangkut teoritis tentang hakikat Aspek perkembangan Anak usia dini, metode pembelajaran.
Tahap kedua, melakukan perencanaan (planning), yang dalam penelitian ini melakukan serangkaian kajian pustaka dan teori (Studi Literatur), diskusi dengan para guru dan kepala sekolah, para pakar pendidikan. Kemudian mendapatkan temuan, konsensus, proposisi, dan generalisasi untuk dipahami (verstehen) terhadap materi-materi pendidikan di Taman kanak-kanak yang cocok diberikan kepada anakanak tingkat Taman Kanak-kanak, focus group discussion dengan para guru, kepala sekolah, dan Dinas Pendidikan Provinsi dan kota. Hal ini tentu saja mempengaruhi volume materi tulisan dan berbagai pendapat para ahli.

\section{Tahap}

ketiga, mengembangkan pembelajaran (develop preliminary form of product) dalam penelitian ini merupakan desain model bahan ajar tematik terpadu berbasis pendekatan saintifik terkait dengan persiapan proses pembelajaran menyangkut materi, proses dan evaluasi dengan melakukan sosialisasi berupa diskusi bersama berbagai kalangan. 
Tahap keempat, sebelumnya sudah dilakukan ujicoba terbatas pada tahun kedua, maka dikembangkan instrumen ukur sesuai dengan kegiatan yang dikembangkan, dikalibrasi dan kemudian dilakukan ujicoba terbatas di lapangan (preliminary field testing) untuk menjustifikasi pembelajaran yang dikembangkan yang dalam penelitian ini dipadukan dengan metode action research dengan menggunakan dua putaran siklus saja, yaitu melalui fase permulaan (initiation), fase penemuan (detection), dan fase keputusan (judgment). (Schumck 1996: 50-52)

Tahap kelima, pada tahap ke lima melakukan revisi (main product revision) melakukan focus group interview yang terdiri dari para guru TK dan kepala sekolah di lokasi ujicoba. Setelah pendidikan final maka dilakukan Ujicoba efektifitas pembelajaran.

Tahap keenam, difusi luas yang dalam penelitian ini sosialisasi secara makro dilakukan pada tahun ke dua.
Hasil nya dari penelitian ini adalah menghasilkan draft Tematik terpadu dan berbasis pada pendekatan saintifik untuk di taman kanak-kanakyang masuk proses penyempurnaan melalui penelitian lanjutan dengan pengembangan tema-tema. Tema tersebut dikembangkan dari tema-tema yang sudah ada, hanya saja lebih spesifik kepada materi yang terkait dengan tema yang dekat dengan anak usia dini baik di lingkungan sekolah maupun lingkungan sekolah. Proses belajar mengajar dilakukan melalui pendekatan saintifik. Proses pemerolehan pengetahuan anak melalui pendekatan pengamatan kepada media yang dapat memberikan penjelaskan kepada anak terkait dengan tema. Proses pemerolehan pengetahuan anak melalui proses Tanya jawab antara anak dengan guru, atau antara anak dengan anak. Proses pemerolehan pengetahuan anak melalui mengumpulkan informasi, baik itu melalui membaca buku, diskusi, dan mencari dalam internet yang dibimbing oleh guru. Pemerolehan informasi juga dapat dilakukan 
melalui asosiasi atau menghubungkan informasi yang lama dengan yang baru. Dan pemerolehan informasi dapat diperoleh anak dalam bentuk mengomunikasikan.

\section{KESIMPULAN}

Kesimpulan dari penelitian ini adalah, bahwa pengembangan bahan ajar tematik terpadu berbasis Pendekatan saintifik sangat diperlukan oleh guru-guru dalam melakukan kegiatan proses belajar mengajar di Taman Kanak-kanak, hal itu dapat di lihat dari hasil Focus Group Discussion yang mana guruguru sangat mengharapkan tematema pembelajaran dapat diselesaikan lebih cepat, karena meraka sangat membutuhkan panduan. Selama ini mereka tidak mendapatkan gambaran tentang pembelajarantematik terpadu melalui pendekatan saintifik. Dari hasil penelitian yang melakukan 6 tahap penelitian pengembangan, sudah dapat menghasilkan tema-tema yang dapat dijadikan sebagai bahan ajar bagi guru-guru di Taman kanakkanak. Namun hal ini belum sempurna karena masiih banyak yang harus dikejakan yaitu khususnya terkait dengan bahan ajar, karena hasil pada tahun pertama baru pada tahap pengembangan tema dan proses kegiatan pembelajarannya.

\section{DAFTAR PUSTAKA}

Arikunto, Suharsimi, Prosedur Penelitian (Suatu pendekatan praktek) PT.Rinekacipta, Jakarta 2006 p 196

Borg Walter R., Meredith D.Gall, Educational Research, New York; Longman, 1989

Cathy Malley. National Network for Child Care. Avalaible at: http://www.nncc.org/child.dev.html

Cook. Thomas D, Campbell. Donald T, Quasi-Experimentation (Designs \& Analysis Issues for Filed Settings, USA, 1979 pp 95107

Depdiknas Kurikulum Hasil Belajar Anak Usia Dini (Jakarta: Puskur.2002)

Hosnan. (2013) Pendekatan Saintifik dan Kontekstual dalam Pembelajaran Abad 21 (Kunci Sukses Implementasi Kurikulum 2103) Ghalia Indonesia, Bogor.

Jackman. L.Hilda. Early Education Curriculum (A Child's Connection to the world). NY: Cengage Delmar Learning. 2009

Seefeldt Carol \& Nita Barbour. Early Childhood Education. NewJersey: PrenticeHall. 1998 
JURNAL PENDIDIKAN USIA DINI

Volume 11 Edisi 1, April 2017

Semiawan Conny R, "Catatan Kecil tentang Penelitian dan

Pengembangan Ilmu

Pengetahuan" (Kencana Prenada Media Group, 2007) pp.181-187

Schmuck A Richard. Practical Action Research for Change (USA:IR/SKYlightTraining and Publishing, Inc, 1996) p.50-52

Suryana. Dadan. Pendidikan Anak Usia Dini (Teori dan Praktek Pembelajaran) UNP Press, Padang (2013)

Sudijono, Anas, Pengantar Statistik Pendidikan, PT.Raja Grafindo Perkasa, Jakarta, 2008 p.206, dan Arikunto, Suharsimi, Prosedur Penelitian suatu pendektan praktik, PT.Rineka Cipta, Jakarta, 2006. p170 